ESJ Social Sciences

\title{
Sectorial Analysis of the U.S. and China Trade Conflict
}

\author{
Anthony Okafor, PhD \\ University of Louisville, U.S.A \\ Edward Agbai, PhD \\ Emmanuel University, U.S.A \\ Funminiyi Egbedoyin, PhD \\ Walden University, U.S.A
}

Doi:10.19044/esj.2021.v17n1p68

Submitted: 02 December 2020

Accepted: 18 January 2021

Published: 31 January 2020
Copyright 2021 Author(s)

Under Creative Commons BY-NC-ND

4.0 OPEN ACCESS

Cite As:

Okafor A., Agbai E. \& Egbedoyin F. (2021). Sectorial Analysis of the U.S. and China Trade Conflict. European Scientific Journal, ESJ, 17(1), 68.

https://doi.org/10.19044/esj.2021.v17n1p68

\begin{abstract}
The impact of the U.S - China trade conflict extends beyond both nations' economies to the economies of trade allies and non-trading partners caught in the web of the trade impasse. This paper conducts a sectoral analysis of the trade conflict on the U.S economy using the manufacturing, agriculture, and technology sectors as metrics. We explore data from the databases of the U.S Census Bureau and the U.S Bureau of Economic Analysis from 2001 to 2019. The trade conflict has led to a significant reduction in trades between both nations. The $25 \%$ counter tariff imposed by China reduced U.S exports by $\$ 30$ billion between 2018 and 2019. Primary income receipts declined 10\%, and secondary income receipts declined further in the negative territory. China's counter-tariffs increased component costs for the U.S automobile industry, leading to a reduction in the number of new and used vehicles sold during the period. We identify an incentive-driven trade policy framework against the current punitive stance, the resumption of trade negotiations, and leveraging the WTO's instrumentality as measures to resolve the current trade conflict.
\end{abstract}

Keywords: Trade Conflict, Effect of Trade Tariffs, Global Trade, U.S and China 


\section{Introduction}

The unfolding global economic scenario dictated by the U.S - China trade dispute is generating significant attention, obviously because of its farreaching implication. The effect of the trade war is not only being felt by the economies of both nations, but transcends the walls of both countries to reach other smaller and poorer economies caught in the web of the trade conflict. The trade war is having a negative implication on the international trading system as companies in the U.S with huge exposure to China battle to deal with the external shocks.

Following the accession of China to the world trade organization (WTO), the world witnessed significant flows of foreign direct investments, which appear to have peaked in 2007 before the global financial crisis. China rose to become the second to the U.S in terms of purchasing power parity and has continued to dominate global trade across different regions, including Europe, Asia, Africa, and South America, using its Belt and Road Initiative. The present trade tensions and the more combative relationship between the two leading economic powerhouses present the most significant threat to globalization. The trade war has led to a gradual decimation of globalization and a departure from multilateral cooperation for nationalistic tendencies and doctrines. The trade tensions are exacerbating global economic uncertainty, and the world trade organization recently warned of downside risks and loss of economic momentum as a result.

The trade conflict is having a significant economic impact on both sides and has frozen investment flows to both the United States and China. The U.S economy declined for the first time since 2014 and had its worst quarterly decline since 2008 during the global financial crisis. In the U.S, three major sectors have been most affected by the trade dispute, namely Agriculture, Manufacturing, and Technology. Farmers appear to be the worst hit by the trade dispute, with most farmers affected going bankrupt. The manufacturing industry hit lows in proportions last seen since the great recession. The restrictions placed on the exportation of American Information Communication and Technology (ICT) products and semiconductors are having major setbacks for the U.S technology industry. The consequence of the trade conflict is that most companies in the affected industry have slowed down hiring while others are right-sizing leading to loss of jobs in the economy. The U.S trade deficit with China remains elevated even though it declined from $\$ 419$ billion in 2018 to $\$ 345$ billion in 2019. The unintended consequence of U.S's unilateral tax imposition on China is that why investment flows declined in China, the U.S. trade deficit with Europe, Mexico, Japan, South Korea, and Taiwan widened as a result (Hass \& Denmark, 2020). 
Economists are united in their submission that the U.S consumers are the ones bearing the brunt of the U.S -China trade dispute. The decline in U.S producers' export opportunities has implications for economic productivity, job growth, and income levels. This study presents a sectoral analysis of how the trade dispute between U.S - China is impacting the U.S manufacturing, agriculture and technology industries. We also explore the impact of trade disputes on the U.S government's primary and secondary income receipts since the beginning of the trade dispute.

The paper is structured as follows. Section 2 presents a historical perspective of the trade dispute between the two parties. Section 3 contains our assessment of the effect of the trade war on the manufacturing, agriculture, technology industries, and the primary and secondary income receipts of government, while section 4 contains the recommendations and conclusion.

\section{Historical Perspective}

Trade wars are usually a consequence of trade disputes arising from disagreements between two conflicting countries. Trade wars can be triggered when there is a flagrant violation of trade agreements and when attempts at resolving the conflict using the instrumentality of the world trade organization have been unsuccessful. Formal trades in documented history between the U.S and China began in 1784 during the then Qing dynasty, with the trade balance tilting in favor of the Chinese (Hur, 2018). In an attempt to close the trade deficit, American traders adopted the strategy of smuggling opium into the Chinese market. While this measure significantly reduced the trade deficit, it led to a serious confrontation between the U.S and China, with the latter placing a total ban on the consumption of opium. This would eventually culminate in the 1839 Opium War and the beginning of the rivalry between China and the Western powers on international trade.

The period between 1920 and 1965 marked both a transition and confrontation period between the U.S and China. The formation of the People's Republic of China in 1949 by the communist party led to further agitation between the U.S and China. Even though both countries appeared to have made appreciable gains during this period, China clashed with the U.S on ideological differences during the Korean War (Holton \& Wang, 1989). This further worsened the conflict between both nations and the cut off of trades between both countries. However, by 1971, the quest to defeat a common enemy in the form of the Soviet Union brought the U.S and China together. Their trade relations improved, and the U.S began to identify China as a strategic partner, paving the way for China to join the International Monetary Fund (IMF) and the World Bank in the 1980s (Fenwick, 1984). Tensions between both nations resurfaced following the Tiananmen Square incident in 1989. The U.S's insistence on being the world's police monitoring 
other nation's compliance with democratic tenets has always sparked tensions between the U.S and China.

The mistrust between both nations continued even after China's accession to the world trade organization, sometimes leading to bilateral disputes affecting their trade relations (Hur, 2018). Of the 42 trade disputes brought against China since joining the WTO, most cases have been initiated by the U.S. The claims are related mainly to intellectual property violations and trade rights. The current spat between the two nations began in 2017 after Donald Trump won the U.S presidential election. President Trump anchored the administration's trade policy on three factors: equalizing trade balances between trading partners, moving against trade partners like China that have been accused severally of manipulating its currency to gain an unfair trade advantage and dismantling unfavorable trade agreements (Noland, 2018). This led to the administration withdrawing from several bilateral trade and multilateral trade agreements. The Trump administration threatened to exit the North American Free Trade Agreement (NAFTA) that came into force in 1994 unless it was renegotiated with the sole aim of reducing the U.S trade deficit. The administration got its wish, and NAFTA was replaced with the United States-Mexico-Canada Agreement (USMCA) in July of 2020. Other trade agreements exited by the Trump administration include the Trans-Pacific Partnership (TPP), Korea-United States Free Trade Agreement (KORUS FTA), the Paris climate accord, and the Iran nuclear deal.

The trade tension between China and the U.S took a dramatic turn in 2017 when the Trump Administration opposed granting China the market economy status at WTO, citing the Chinese communist party's pervasive role in the economy and its arbitrary use of subsidies, which places other members at the receiving end. Further, the U.S imposed \$200 billion tariffs on Chinese exports to prevent the dumping of Chinese products in the U.S economy and correct the trade imbalance between both nations. In a retaliatory move, China raised its tariffs from $10 \%$ to an average of $25 \%$ on American exports, which are considerably less than $\$ 200$ billion a year. There have been concerns that the current trade impasse between both countries is because of the U.S's unwillingness to come to terms with China's domineering control of global supply networks. Figure 1 shows that most countries depend on China for their industrial supply chains. As such, decoupling is a remote and unattainable solution to the current trade conflict. 
Figure 1. Global Electrical and Electronics Supply Chain through China

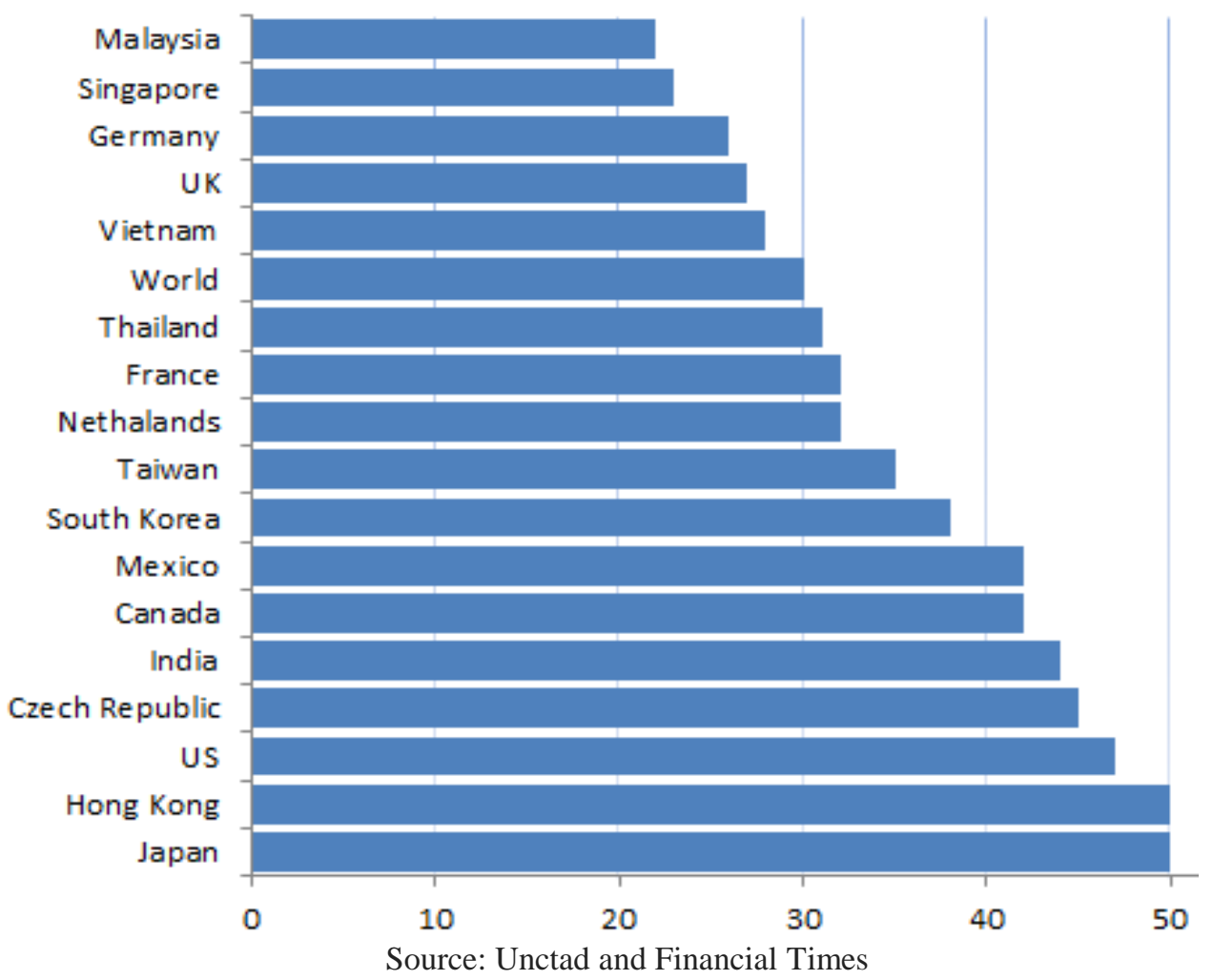

The chart shows that $30 \%$ of global electrical and electronic equipment passes through or is supplied by China. In comparison, the U.S relies on China to meet about $50 \%$ of its electrical and electronic equipment demands. Consequently, the current impasse is of significant interest to the U.S and other trade partners. The trade conflict is already taking a toll on the average Americans operating or working in the sectors targeted by the U.S tariffs and China's counter-tariffs.

\section{Post Tariff Literature Review}

Since the advent of the trade tension between China and the U.S in 2017, a couple of scholars have intervened in the trade conflict between the U.S and China. Adjemian, Smith, \& He (2019) utilized the relative price of a substitute method to investigate the impact of the trade tariff on the U.S soybean market. The study finds that the impact of China's tariff on U.S producers was not homogeneous but generally led to the lowering U.S export prices. Other local factors that impacted local producers include transportation infrastructure, storage capacity, and proximity to crush facilities, played a major role. 
Amiti, Redding, \& Weinstein (2019) examined the impact of the Trump administration's trade policy on price levels and welfare in 2018. The study finds that real income reduced by $\$ 1.4$ billion per month throughout 2018. Disaggregating the data, they observe that the full effect of the trade tariff was passed on to U.S consumers because of the substantial changes observed in supply chain networks, increases in prices of imported products, and the overall reduction of imported products. Li, Balistreri, and Zhang (2020) used a standard off-the-shelf general-equilibrium simulation model to examine the effect of the tariff increases on the people's welfare. The study finds that phase one of the trade deal worsened consumer welfare in China by $1.7 \%$ while that of the United States decreased by $0.2 \%$.

Chong \& Li (2019) compared the current trade war between the U.S and China with similar trade wars in history, focusing on how it impacts China. The study identifies global economic dominance, U.S midterm elections, and trade imbalances as the three major causes of trade wars between the two nations in recent history. The study projects the trade tariff's impact on China to be a $1.1 \%$ decrease in employment and a loss of $1 \%$ of the country's GDP. The effect on the U.S has also been significant. Meltzer and Shenai (2019) note that between 1999 and 2011, U.S trade with China has led to 560,000 job losses in the manufacturing industry.

Aaron and Pierce (2019) estimated the effect of the U.S trade tariffs and the retaliatory tariffs imposed by U.S trading partners on output levels, producer prices, and manufacturing employment in the U.S. They find that U.S trade tariffs and counter-tariffs led to a reduction in employment for manufacturing industries more exposed to the trade tariffs. Aaron and Pierce (2019) note that higher tariffs were positively correlated with relative increases in output price levels occasioned by rising input costs. Cavallo et al. (2019) utilized microdata to characterize the effects of US trade tariff imposed on China on U.S importers, exporters, and consumers. The study finds that the effect of the trade tariffs on price levels was mixed and that retailers in some product categories lowered their margins to accommodate the impact of the tariffs on consumers while others passed the full effect of the trade tariffs on consumers.

Contrary to the expectation that the U.S government's tax increases will lead to significant inflows in terms of tariffs, Amiti, Redding, and Weinstein (2020) note that U.S companies are the ones indirectly paying the tariffs. An estimated amount of $\$ 46$ billion was paid in tariffs by American companies. The strategies adopted include accepting reduced margins, cutting jobs for U.S workers, freezing wage hikes, and passing the effect of the tariffs on U.S consumers by raising prices. In addition, Chinese retaliatory actions against the import of U.S farm produce have put to risk the once-booming \$24 billion market in China. China is also suffering the effect of U.S tariffs as the 
U.S market has become more competitive for other players leading to trade diversion away from China. Recent statistics indicate that $63 \%$ of the $\$ 35$ billion Chinese export to the U.S has been diverted to other countries, and the balance is either lost or taken over by U.S producers. The European Union and countries like Mexico and Taiwan are experiencing a surge in the sales of office machinery, communication equipment, agri-food, and transport equipment to the U.S market.

\section{Analysis of Current Trade Impasse}

In assessing the macroeconomic impact of the current trade impasse on the U.S economy, we identify three sectors, including the manufacturing, agriculture, and technology sectors. We utilize content and descriptive analysis to examine how the trade war is affecting the U.S economy. We explore data from the U.S census bureau and U.S Bureau of Economic Analysis from 2001 to 2019. Manufacturing data from 2001-2019 were obtained from the U.S Bureau of Economic Analysis, while imports and exports data were obtained from the U.S Census Bureau database. Data related to primary and secondary income receipts, in addition to the current and capital account balances, were also obtained from the database of the U.S Bureau of Economic Analysis.

The descriptive analysis in Table 1 measures the effect of the trade tariff on the trade volumes between U.S and China between 2017 and August 2020. The U.S census bureau tracks monthly data of the trade volumes between U.S and China since 1985. The dataset shows that since the beginning of the new tariff regime, U.S exports to China have declined by $18 \%$, while imports from China declined by 11\% between 2017 and 2019, and Chinese imports of products are affected by the new tariffs declined even stronger by $25 \%$.

Table 1: Trade Volumes between U.S and China

U.S Exports to China

\begin{tabular}{llllc}
\hline Year & 2017 & 2018 & 2019 & $\begin{array}{c}2020 \\
\text { (Jan-Aug) }\end{array}$ \\
\hline Trade (\$ Bn) & 130.00 & 120.29 & 106.45 & 69.56 \\
$\begin{array}{l}\text { Cumulative } \\
\text { Trade (\$Bn) }\end{array}$ & 130.00 & 250.29 & 356.73 & 426.30 \\
\hline
\end{tabular}

U.S Imports from China

\begin{tabular}{llllc}
\hline Year & 2017 & 2018 & 2019 & $\begin{array}{c}2020 \\
\text { (Jan-Aug) }\end{array}$ \\
\hline Trade (\$ Bn) & 505.17 & 539.24 & 451.65 & 262.68 \\
$\begin{array}{l}\text { Cumulative } \\
\text { Trade (\$Bn) }\end{array}$ & 505.17 & $1,044.41$ & $1,496.06$ & $1,758.74$ \\
\hline
\end{tabular}

Source: U.S Census Bureau 
Further analysis from the dataset shows an uptick of $21 \%$ between 2017 and 2019 in U.S imports from China on goods not affected by the hike in tariffs. We observe an initial surge of U.S imports from China on the tariffed products as both nations sought to resolve the trade impasse between 2017 and 2018. Chinese exporters sold more tariffed products to the U.S in 2012 in anticipation of further tariff hikes. An additional hike in tariffs saw U.S imports from China decline by about $\$ 70$ billion in 2019. China maintained a steady import of non-tariffed products from the U.S between 2017 and 2019. Similarly, we notice a significant decline worth over $\$ 30$ billion in China's import from the U.S between 2018 and 2019.

Table 2: Impact of Tariffs on Trades between U.S and China

\begin{tabular}{lcccccc}
\hline & \multicolumn{3}{c}{ U.S Imports from China } & \multicolumn{3}{c}{ China Imports from U.S } \\
\hline Year & 2017 & 2018 & 2019 & 2017 & 2018 & 2019 \\
$\begin{array}{l}\text { Non-tariffed } \\
\text { Products }\end{array}$ & 10.81 & 12.49 & 13.10 & 42.22 & 46.42 & 40.89 \\
Tariffed Products & 508.71 & 543.81 & 470.13 & 107.51 & 107.03 & 77.84 \\
\hline
\end{tabular}

Source: U.S Bureau of Economic Analysis and Authors Computation

Imports from all the sectors affected by the tariff faced a negative growth rate between 2018 and 2019 with petroleum, agricultural products, and metals being the most impacted. Instead, we observe an upsurge in Chinese imports of U.S products, especially the non-tariffed products such as computer and electronic equipment necessary to support the Chinese economy before the second phase of the U.S trade restrictions came into force.

\section{Manufacturing}

While the duties imposed by the U.S government are providing some import protection to U.S firms, the Federal Reserve has noted that an increase in input costs, production expenses, and retaliatory tariffs outweigh any benefits derivable from the imposed tariffs (Winck, 2020) ${ }^{1}$. According to a Federal Reserve study, the new tariffs are harming the manufacturing sector, and the sector has cut and posted the most job losses in the last four years (Aaron, \& Pierce, 2019). As shown in Figure 1, manufacturing output is down significantly in 2019 to its lowest volume in a decade after seeing an initial surge in 2018. If this trend continues and taking into consideration the effect of COVID 19 on the sector, the manufacturing industry might well experience its worst performance in 2020.

\footnotetext{
${ }^{1}$ ibisworld Manufacturing in the US Number of Businesses 2002-2026, https://www.ibisworld.com/industry-statistics/number-of-businesses/manufacturing-unitedstates/
} 
The U.S - China trade war is beginning to impact the manufacturing sector in the U.S as the price of manufacturing inputs, especially those coming from China, has increased significantly because of the tariff. The U.S is losing on many fronts against China. First, with China retaliating against the tariffs, U.S exports have become more expensive, making it harder to sell U.S products in China. Second, since input costs are soaring, U.S manufacturers are becoming less competitive, given the presence of alternatives and substitutes from other sources. Third, U.S manufacturing output and sales have dropped domestically due to the high input costs coupled with the present state of the U.S economy.

Figure 2a - U.S Manufacturing Growth Rate 2016 to 2020

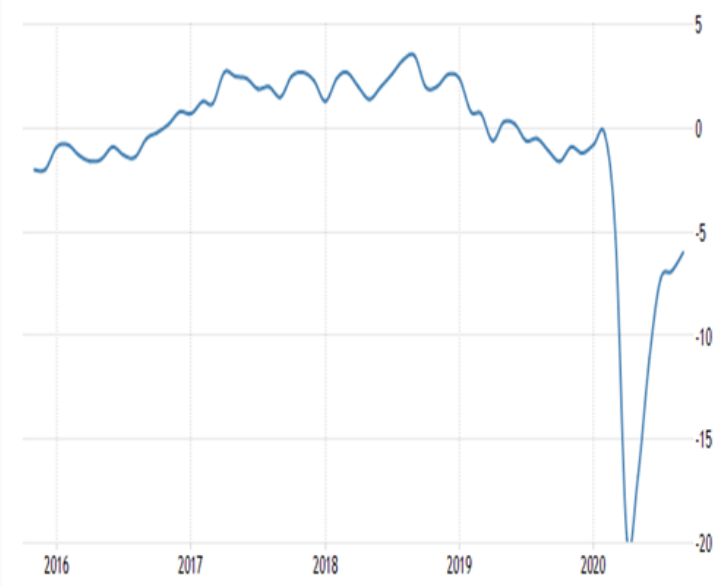

Figure 2b - U.S Manufacturing output 2001 to 2019

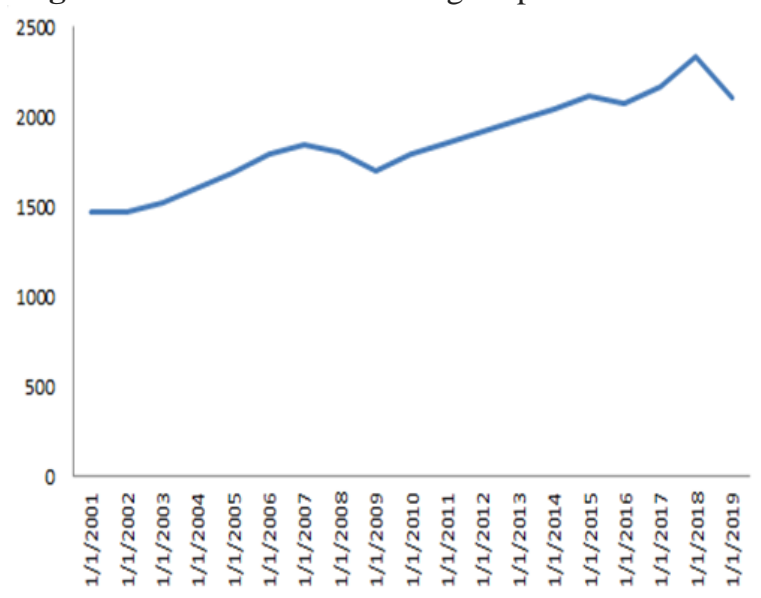

The unintended consequence of this trade war is now becoming apparent. Exports of goods and services have fallen since year-end 2018. Export volumes and income receipts are down from a peak of $\$ 954$ billion in quarter three of 2019 to $\$ 902$ billion in quarter one of 2020 , even before the 
pandemic set in. Companies in the automotive, parts and engines industry have felt the pinch the most, seeing their output decline by $\$ 3.6$ billion just in quarter one of 2020. The number of manufacturing businesses operating in the country declined from 614,418 in February of 2019 to 565,537 in February of $2020^{2}$. The decline in the number of businesses started long before the pandemic hit the U.S economy.

Americans are bearing the direct impact of the trade disputes. JPMorgan puts the average cost on U.S households at \$1000 (Fitzgerald, 2019). Additionally, U.S producers are battling with trade diversions from China as 65\% of U.S exports have been lost in 2019 compared to 2017 overall export figures. Most staple consumer goods in the U.S have more expensive, with the U.S government taking measures to lessen the impact of the trade war on U.S consumers. Alternatively, in China, exporters are experiencing a significant decline in their export volumes to the U.S, which is China's single largest export market.

The U.S automobile industry is the most affected by the U.S - China trade tensions given the $40 \%$ tariff placed on U.S made automobiles. The tariffs on steel and aluminum products have already begun to create supply chain disruptions for U.S car manufacturers. Added tariffs increase the cost of components coupled with the difficulty of replacing offshore suppliers at short notice. Given the level of sophistication, quality, and precision required from suppliers of input materials in the industry, replacing the existing suppliers could take between 6 and 10 years to achieve. Rising prices of aluminum and steel products have added millions of dollars in unplanned costs. As noted recently, the former FORD CEO Jim Hackett notes that the increased tariff could lead to losses in excess of $\$ 1.0$ billion in the short term. Additionally, Americans are expected to pay more for U.S cars, which could be as much as $\$ 6000$ for vehicles that would typically cost $\$ 35,000$ on average.

Figure 1 shows the trade volume in passenger vehicles and light trucks exported to China between 2004 and 2019. The impact of the trade conflict can be seen in the dwindling sales since the idea of the new tariff was muted. Since the introduction of the $25 \%$ tariff on steel and aluminum products, U.S car sales have dropped by over $27 \%$.

\footnotetext{
${ }^{2}$ Trade in Goods with China, https://www.census.gov/foreign-trade/balance/c5700.html
} 
Figure 3: Used Car Sales 2010 to 2019

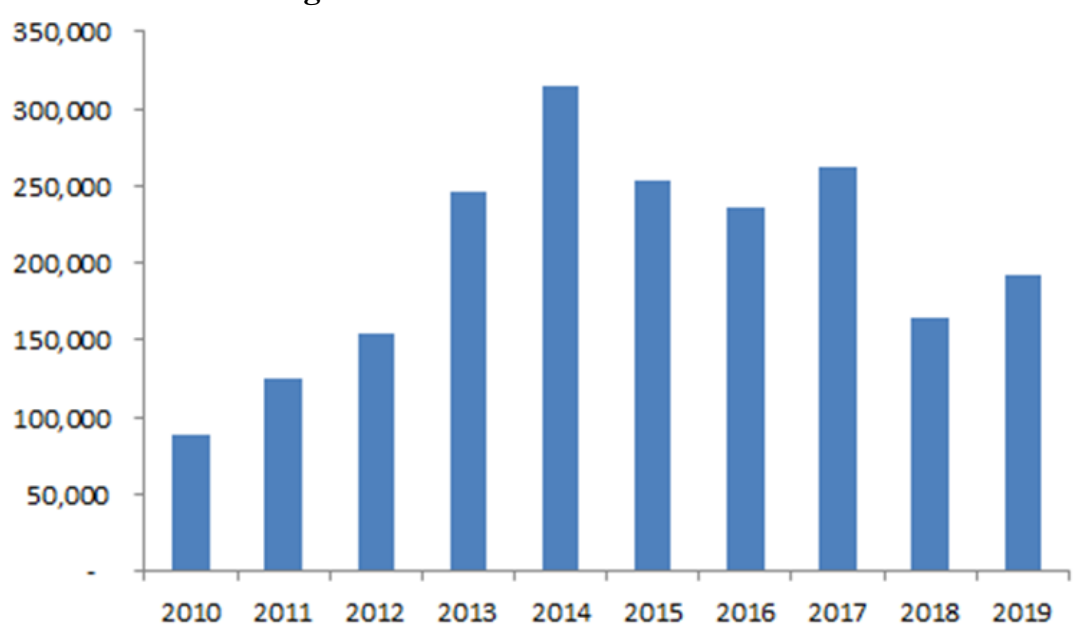

Source: United States Department of Commerce, Bureau of the Census, Foreign Trade Division \& Statista

\section{Agriculture}

The third worst hit sector by the trade tensions in the U.S after automobiles, technology is agriculture with most companies in this sector facing bankruptcy. U.S farmers are also bearing the brunt of the trade escalation between the two countries. China is the fourth largest importer of U.S farm products, which stood at $\$ 9.5$ billion at the end of 2018. The retaliatory tariffs have had a significant impact on U.S. agricultural exports to China, which declined by $\$ 15$ billion at the close of 2019 (Carter \& Sandro, 2019). In the wake of the trade conflict, U.S farmers were offered $\$ 28$ billion in subsidies, which is twice the 2009 bailout given to the auto industry. U.S exports to China have dropped xx\% from $\$ 13.6$ billion in December 2017 to $\$ 7.91$ billion in March $2020^{3}$. In Table 1, we show China's reaction to U.S tariffs by selecting some and how this has led to a spike in product cost.

${ }^{3}$ Trump's tariffs are driving job losses and production cost hikes, the Fed says Ben Winck Jan 2, 2020, https://markets.businessinsider.com/news/stocks/trump-tariffs-driving-job-lossesproduction-cost-hikes-fed-says-2020-1-1028791979\# 
Table 3: China's Response to U.S Tariff

\begin{tabular}{lrrr}
\hline Commodity & $\begin{array}{r}2017 \\
\text { Tariffs(\%) }\end{array}$ & $\begin{array}{r}2018 \\
\text { Tariffs(\%) }\end{array}$ & $\begin{array}{c}2019 \\
\text { Tariffs (\%) }\end{array}$ \\
\hline Almonds, In Shell & 10 & 25 & 35 \\
Almonds, Shelled & 10 & 25 & 35 \\
Grapes, Fresh & 12 & 27 & 30 \\
Frozen Sockeye Salmon & 7 & 25 & 37 \\
Frozen Yellowfin Tunas & 7 & 25 & 37 \\
Oranges, Fresh & 12 & 27 & 35 \\
Pistachios, In Shell & 5 & 20 & 30 \\
Pistachios, Shelled & 5 & 20 & 30 \\
Seed Potatoes & 13 & 20 & 40.5 \\
Sparkling Wine & 14 & 30 & 29 \\
Walnuts, In Shell & 24 & 40 & 50 \\
Walnuts, Shelled & 20 & 35 & 50 \\
Wine & 14 & 30 & 35 \\
\hline
\end{tabular}

Source: USDA FAS Report Number: CH2019-0194 \& CH2020-0016

The U.S accounts for $86 \%$ and $71 \%$ of world exports of almonds and pistachios, respectively. China remains the world's leading exporter of Walnut. U.S. export of Walnut has declined by $50 \%$ since the beginning of the trade war (Carter \& Sandro, 2019). However, as part of the trade agreement reached between the U.S and China, China is expected to purchase $\$ 200$ billion worth of U.S products with agriculture, pharmaceutical, and energy services leading the pack. This agreement remained in force prior to the COVID 19 pandemic, which further strained the trade relations between both countries.

Another product that has been massively impacted is U.S soybeans. China remains the largest importer of soybeans from the U.S, contributing $\$ 3.1$ billion to the U.S economy in 2018. Other agricultural products imported in high quantity include Cotton (\$924 million), hides and skins (\$607 million), pork products ( $\$ 571$ million), and grains ( $\$ 530$ million). Soybeans contribute about $\$ 12.8$ billion to the U.S economy. Half of this has historically been absorbed by China. Following China's 25\% retaliatory tariff on Soybeans import, U.S managed only 8.3 million metric tons of soybeans exports in 2018 compared to 32 million metric tons exported in 2017. Chinese buyers have remained the major importers of soybeans from the U.S due to China's huge hog herd. The retaliatory tariff continues to have a significant impact on the volume of U.S soybeans imported by China. While other trading partners and nations such as the European Union, Egypt, and Argentina have moved in to purchase more soybeans from the U.S, the added demands are not able to 
offset the losses from China due to the trade conflict and trade diversion (Adjemian, Smith, \& He, 2019).

\section{Technology}

Another sector of the U.S economy affected by the trade disputes is the tech industry. The U.S tech industry is highly exposed to China for manufacturing and sales of semiconductors, a major input used by most tech companies. The U.S - China trade conflict has led to collateral damage for U.S tech firms ${ }^{4}$. However, disagreements between both nations on violation of intellectual property rights predate Trump's administration. China has been fingered in intellectual property violations over the years, and this has been a significant cause of conflict between the U.S and China. One of the reasons put forward by the Trump's administration for revising upward tariffs on imports from China leveraging Section 301 of the 1974 Trade Act includes poor protection of intellectual property rights, forced technology transfer from foreign companies investing in China, and the heavy involvement of the Chinese government in the subsidization of state-owned companies (Bekkers \& Schroeter, 2020).

In 2018, Washington announced a $25 \%$ tariff on $\$ 50$ billion worth of imported equipment and materials from China even if inputs materials or components were made in the U.S. Data from the U.S Department of Commerce indicates that nearly $60 \%$ of semiconductors imported into the U.S from China were re-imported back to the U.S by U.S semiconductor producers $^{55}$. The remainder being imports from European Union, South Korea, and Japanese companies affiliated with Chinese companies and not Chinese producers ${ }^{66}$. As part of the trade conflict, Trump's administration is restricting the export or sales of sensitive U.S technologies to some select Chinese companies and barring Chinese companies from investing in the U.S citing security concerns.

The first major victim of the trade tensions is Huawei, which has been at the center of the trade conflict between both nations over issues of technology and security. The Trump administration had sanctioned Huawei for acting as a spy organization and tool of the Chinese communist party. Washington decided to restrict Huawei's access to U.S components and technology. The administration extended this restriction to vendors producing components and equipment for Huawei. The sanction restricts vendors across the world from the use of U.S technology to produce components for Huawei.

${ }^{4}$ Ana Swanson and Cecilia Kang, Jan 20, 2020. Trump's China Deal Creates Collateral Damage for Tech Firms, https://www.nytimes.com/2020/01/20/business/economy/trump-uschina-deal-micron-trade-war.html

${ }^{5}$ Source: Official U.S. government trade data, U.S. Department of Commerce

${ }^{6}$ Official U.S. government trade data, U.S. Department of Commerce, U.S. Census Bureau 
Specifically, the rule prohibits the use of American software or American fabrication equipment to produce components for Huawei without authorization ${ }^{77}$. The applied sanctions have almost upended the once-thriving Chinese tech giant and its quest to roll out the 5G technology. Huawei, leveraging on its homegrown semiconductor production unit and other substitutes from Japan and other countries, is curtailing its reliance on U.S for chips $^{87}$. The company reported an $18 \%$ jump in sale for full-year 2019 to $\$ 120$ billion, a sign that the company and other related Chinese tech companies are forging ahead despite the restrictions to the detriment of U.S buyers and suppliers.

TikTok, a Chinese-owned messaging app that has attracted hundreds of millions of users worldwide, including the U.S has been drawn into the web of the trade disagreement between both countries. Washington has tagged the continued operation of TikTok in the U.S as a security threat and therefore ordered the ban on its operations in the U.S. The Trump administration would later have a rethink and sanction its continued operation only if their operation in the U.S is sold to a U.S-based firm.

The aggressive approach by Trump's administration appears to be stoking a technology arms race between China and the U.S. Mostly, the quest to outdo one another in the production of semiconductors, artificial intelligence, and other emerging technologies is at the heart of the technology arms race. In a bid to decouple its economy from that of the U.S and to limit its reliance on U.S technological products, China is now concentrating efforts to manufacture its software, semiconductors and expanded the Chinese government's focus on the use of artificial intelligence.

Manufacturers of semiconductors in the U.S are hurting in the face of the trade policy that appears to be strangulating sales to their major semiconductor importer across the world. Table 4 shows U.S. Semiconductor Industry Sales and Market Share by region.

Table 4 U.S. Semiconductor Industry Sales and Market Share

\begin{tabular}{ccc}
\hline Region & Vol.(\$ Bn) & U.S Market Share \\
\hline Americas & 31.5 & $35.60 \%$ \\
Europe & 19.1 & $49.80 \%$ \\
Japan & 14.6 & $40.00 \%$ \\
China & 66.4 & $50.50 \%$ \\
Asia Pacific \& Others & 57.3 & $48.80 \%$ \\
\hline
\end{tabular}

Source: World Semiconductor Trade Statistics and SIA 2017 Estimates

${ }^{7}$ Trump administration imposes new Huawei restrictions By Matt O'Brien, August 17, 2020, https://apnews.com/article/7a01cf8cf13f7681df62094f27b1bcbc 8 
The Semiconductor Industry Association (SIA) notes that disrupting U.S. semiconductor companies' supply chains would hurt and put the industry, which creates over 250,000 jobs, at a disadvantage ${ }^{98}$. While the U.S is implementing the tariff hike, China launched a $\$ 150$ billion support fund to aid its local semiconductor manufacturers, placing them at a huge cost advantage over other players in the industry, especially U.S manufacturers. If the $25 \%$ tariff on Chinese ICT import continues, sales from U.S ICT manufacturers industry is expected to slow by $\$ 332$ billion in the next ten years ${ }^{109}$. Rather than resorting to what appears to be a counterproductive approach to the trade conflict, Washington could adopt more effective and targeted policies at addressing Intellectual Property theft. They could also leverage the instrumentality of the WTO and work synergistically with other allies to combat the various problematic aspects of Chinese industrial policy.

\section{Primary and Secondary Income Receipts}

China being a major U.S trading partner, accounts for a significant proportion of the international trades between both nations. The trade conflict has impacted both primary and secondary income receipts and further expands the negative current account balance as shown in Figure 4.

Figure 4: Balance on Primary and Secondary Income

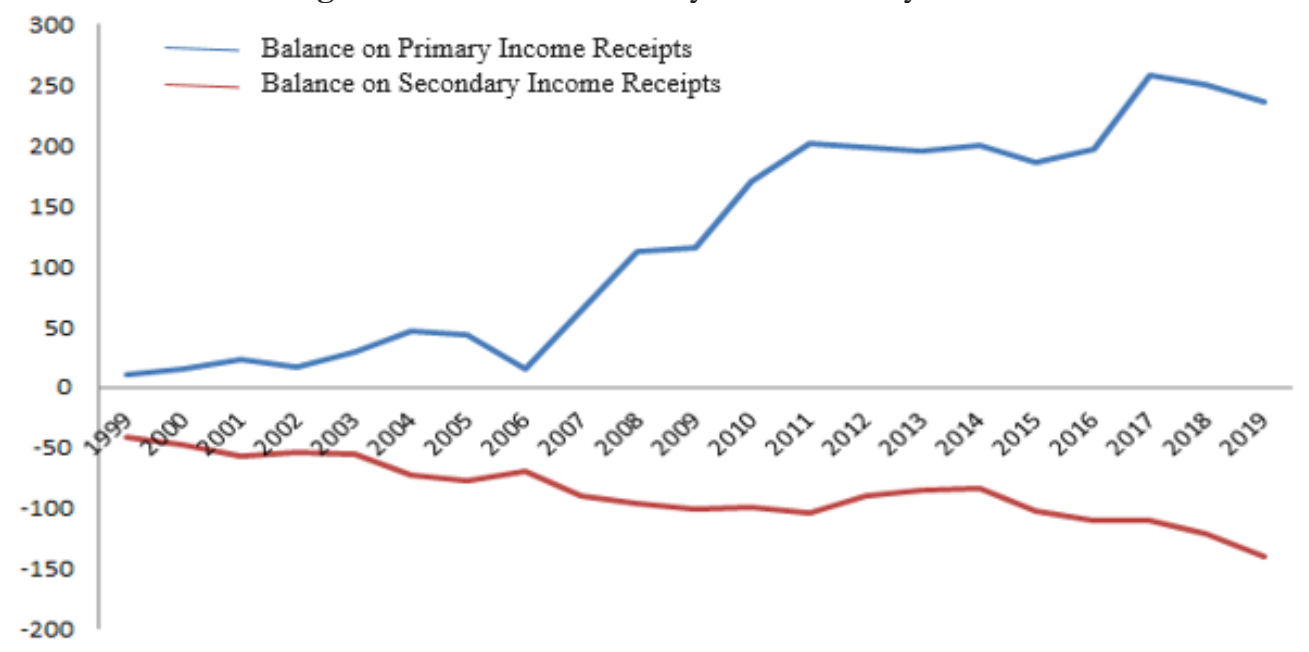

Source: Authors

The primary income receipt has slowed down between 2017 and 2019 after reaching its peak in 2015. Primary income receipt is mainly income from

\footnotetext{
${ }^{9}$ Semiconductor Industry Association (SIA) https://www.semiconductors.org/wpcontent/uploads/2018/08/Final__SIA_Submission_on_301_Tariffs.pdf

${ }^{10}$ Why Tariffs on Chinese ICT Imports Would Harm the U.S. Economy, by Robert D. Atkinson, Stephen J. Ezell, and J. John Wu | March 2018, 1-14. http://www2.itif.org/2018ict-tariffs-china.pdf
} 
the different layers of international transactions related to investments, while secondary income receipts are mainly fees, fines, taxes, and penalties earned by the U.S government on international transactions. Primary income receipt averaged \$284 billion each quarter from 2017 to 2018 and has declined to an average of $\$ 255$ billion in 2019.

Figure 5: Balance on current account

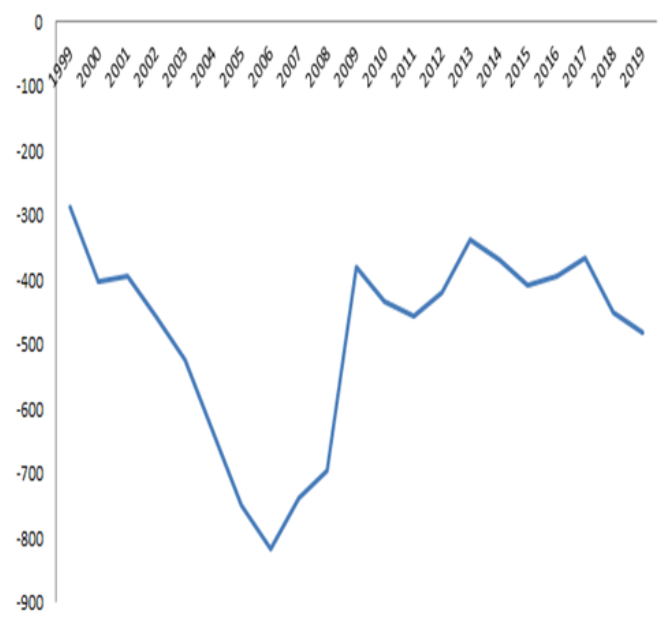

Source: Authors

Figure 6: Balance on capital account

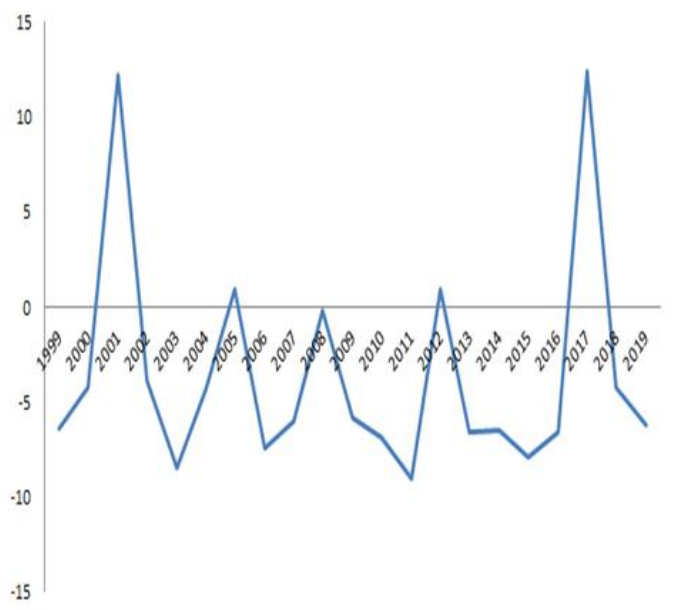

Source: Authors

Secondary income receipt continued in the negative territory, which indicates the slower pace of transactions consummated and fees earned during the period. The seasonally adjusted balance on current account for international transactions expanded even though in negative territory as shown 
in Figure 5 from $-\$ 394,865$ in 2016 to $-\$ 480,226$ in 2019 while the balance on capital account seesawed during the period as shown in Figure 6.

\section{Recommendations}

The potential impact of the trade tariff on the global economy and trade losses is projected at $2 \%$ and $17 \%$, respectively, as the trade conflict's effect is expected to transcend the economies of U.S and China (Bekkers \& Teh, 2019). History has shown that it is difficult to emerge as a winner in a trade war. Whatever gains the U.S might have made is undone by China's retaliatory tariff with the reverberating effect on local businesses. Therefore, it has become imperative for participants and economic managers to agree to stick with multilateral commitments, especially for the U.S as China's influence on the global supply chain continues to grow.

The U.S must come clean on what constitutes a successful or an agreeable trade agreement with China and measurable criteria for assessing its success. Attempts to use trade tariffs to dissuade China from expanding its innovative capacity will definitely be seen as an infringement on China's sovereignty. One of the ways the U.S and China can begin to recouple is to resume discussions on how to achieve a win-win trade agreement between both parties in a fair, equitable, and transparent manner. Without a genuine commitment to resolving the trade impasse, the effect could be dire for the U.S economy if added to this trade conflict; it continues to pursue unilateral policies at the expense of its allies. U.S should explore an incentive-driven framework against the current punitive stance, which is bound to lead to more combative exchanges, realignment of economic powers, and the whittling down of U.S's levers of influence across the globe. Washington's decision to withdraw from the Trans-Pacific Partnership Agreement is hurting U.S manufacturers, farmers as well as consumers. U.S can return to this agreement to maintain its leverage with its Asia-Pacific partners, combat China's growing influence within the region, and encourage China to evolve lasting market reforms.

Leveraging the strong ties that the U.S has with its allies is probably another effective measure that Washington could adapt to further pressure China to agree to a more beneficial trade pact with the U.S. However, achieving this can become problematic if Washington abandons multilateralism to pursue protectionism and unilateralism, especially if it continues to decouple for established international agreements and treaties. Therefore, it becomes necessary to stress that complete decoupling is a strategy that would do both countries' economies no good.

Obviously, an equitable and efficient path to resolving the trade war would require a rules-based and multilateral approach, one that could be achieved through the instrumentality of the WTO. The WTO embodies 
American core values of non-discrimination, the rule of law, and transparency and should form the foundation on which the U.S can amass global support to counter Chinese unfavorable economic practices (Meltzer \& Shenai, 2019). Washington must now chart a new course, one that is different from its earlier approach of undermining the WTO despite benefitting so much from it by working synergistically with its allies to restructure the WTO in a manner that guarantees an equitable trade policy framework that works for all. However, for any appreciable progress to be made on China's compliance with WTO trade terms, the U.S must also commit to comply with WTO trade policies.

We strongly canvass for a resolution using the instrumentality of the WTO where China can be made to abide by the dispute settlement mechanism of the WTO because whereas China benefits from multilateralism and the open trade framework of the WTO, China continues to run an economic model in which the state controls both public and private enterprises. Therefore, a sustainable solution would require a political consensus to unite around a global solution aimed at addressing the trade tariff crisis.

Irrespective of the outcome of the current trade impasse is, how the U.S fairs will largely depend on actions taken at home. There will be a need to refocus its domestic policies to engender the competitiveness of its economy. The U.S will also need to tactfully design policies - anti-dumping and countervailing measures, policies that control access to its technologies either through investments or export controls, and the application of WTOtrade consistent policies to push back against Chinese harmful economic activities on U.S businesses.

\section{Conclusion}

The trade conflict between the U.S and China has been a topical issue in the last couple of years, with a significant consequence on the economies of both nations and other trading partners. In this paper, we assessed the impact of the trade conflict on the U.S economy using the manufacturing, agriculture, and technology sectors as a guide. From our assessment, we find that the trade war has had a negative impact on companies in the manufacturing, agriculture, and technology sectors of the economy, leading to losses in export revenues and jobs in the sectors targeted by the trade conflict. Further, we examined the sectoral impact of the trade war on the primary and secondary income balances accruable to the U.S government during the period. We notice a significant decline in the primary income balances since the trade war began in 2017. Secondary income balances expanded in the negative territory during the period. To address this conflict, we advanced four paths to resolving the trade war, which includes using the instrumentality of the WTO and returning to the negotiation table to extract a win-win trade policy framework. A reset of Washington's approach to multilateralism is required. Also, there is the need 
to implement incentive-based access and control to U.S technologies for U.S allies, including China, to address the trade deficits and China's violation of intellectual property rights.

\section{References:}

1. Aaron, F. \& Pierce, J. (2019). Disentangling the effects of the 20182019 tariffs on a globally connected U.S. manufacturing sector. Finance and Economics Discussion Series 2019-086. https://doi.org/10.17016/FEDS.2019.086.

2. Adjemian, M. K., Smith, A., \& He, W. (2019). Estimating the market effect of a trade war: The case of Soybean tariffs 1-20

3. Amiti, M., Redding, S. \& Weinstein, D. (2019). The impact of the 2018 trade war on U.S. prices and welfare. CEPR Discussion Paper 13564, $1-39$.

4. Amiti, M., Redding, S. J., \& Weinstein, D. E. (2020). Who's paying for the US tariffs? A longer-term perspective. In AEA Papers and Proceedings 110, 541-546.

5. Bekkers, E., \& Schroeter, S. (2020). An economic analysis of the U.S - China trade conflict. Staff Working Paper ERSD-2020, Economic Research and Statistics Division World Trade Organization. 1-36

6. Bekkers, E., \& Teh, R. (2019). Potential economic effects of a global trade conflict: Projecting the medium-run effects with the WTO global trade model. WTO Staff Working Paper (No. ERSD-2019-04).

7. Carter, C.A. \& Sandro, S (2019). Impact of the U.S.-China trade war on California Agriculture. ARE Update 23(3) 9-11.

8. Cavallo, A., Gopinath, G., Neiman, B., \& Tang, J. (2019). Tariff pass through at the border and at the store: evidence from US trade policy. National Bureau of Economic Research Working Paper 26396. 1-37

9. Chong, T. T. L., \& Li, X. (2019). Understanding the China-US trade war: causes, economic impact, and the worst-case scenario. Economic and Political Studies, 7(2), 185-202.

10. Fenwick, A. (1984). Evaluating China's special economic zones. Int'l Tax \& Bus. Law., 2, 376-405

11. Fitzgerald, M. (2019). Here's what new tariffs will cost the average American household. https://www.cnbc.com/2019/08/19/heres-whatnew-tariffs-will-cost-an-average-american-household.html

12. Hass, R. \& Denmark, A. (2020). More pain than gain: How the USChina trade war hurt America, Retrieved from https://www.brookings.edu

13. Hur, N. (2018). Historical and strategic concern over the US-China trade war: Will they be within the WTO? Journal of East Asia and International Law11 (393) 1-30 
14. Holton, R. H., \& Wang, X. (1989). US-China economic relations: present and future (No. 29). University of California Institute of East Asian Studies.

15. Li, M., Balistreri, E. J., \& Zhang, W. (2020). The US-China trade war: Tariff data and general equilibrium analysis. Journal of Asian Economics, 69, 1-12

16. Meltzer, J. P., \& Shenai, N. (2019). The US-China economic relationship: A comprehensive approach. Brookings and American Enterprise Institute 1-25

17. Noland, M. (2018). US trade policy in the Trump administration. Asian Economic Policy Review, 13(2), 262-278. 